\title{
OBITUARIES
}

\section{Charles Otto Blagden}

Born on 6th September, 1864, Dr. Blagden died on 25th August, 1949. From Dulwich he won a scholarship to Corpus Christi College, Oxford, where he took a first in Literæ Humaniores. In 1888 he entered the Straits Settlements Civil Service, but in 1897 was forced by ill health to leave Malaya. In 1898 he joined Gray's Inn as a Holt scholar and was called to the bar in 1900. In 1917 he was appointed a Lecturer in Malay at the School of Oriental Studies and before retiring in 1935 was promoted Reader and then Dean. For 1923-1933 and 1935-1938 he was a Vice-President and from 1938-1949 an honorary Vice-President of this Society.

Dr. Blagden wrote many papers and reviews for the Journals of this Society and its Malayan Branch. In 1916 he translated a volume of essays by Renward Brandstetter on Indonesian linguistics. In 1917 he collaborated with me in compiling a Malay Reader, and in 1934 I induced him to send to the press a MS., over which he had long worked, on an English Malay Phrase Book. Between 1920 and 1935 he produced an edition of Mon inscriptions in Epigraphia Birmanica. His greatest single contribution to Malayan research was the comparative vocabulary of aboriginal races in Pagan Races of the Malay Peninsula (1906).

Dr. Blagden was a sound scholar, whose work was invariably reliable. Its quality was some compensation for a temperamental diffidence that hindered productivity. As a teacher he took infinite pains and commanded the affection and respect of his students.

\section{R. O. WINSTEDT.}

\section{Mr. C. N. Seddon}

Charles Norman Seddon, late Indian Civil Service on the Bombay side, died at Oxford at the age of 79. Passing into the Service from Liverpool College in 1889, he spent two years at Balliol College before leaving for India, where he had a distinguished career, mainly in the province and Indian states of Gujarat, being at one time Diwan to the Gaikwar of Baroda, Maharaja Sayajirao III. Seddon's 